Original article

\title{
Traumatology institutions in the early years of the soviet state: a gap in the history of Russian traumatology and orthopedics
}

\author{
Sergei E. Grishin ${ }^{1}$, Vladimir Yu.Ulyanov ${ }^{1}$, Aleksander S.Fedonnikov ${ }^{1}$, Igor A Norkin ${ }^{1}$ \\ ${ }^{1}$ Saratov State Medical University, Saratov, Russia \\ Received 19 January 2021, Accepted 25 February 2021
}

Original Text (c) Grishin S.E., Ulyanov V.Yu., Fedonnikov A.S., Norkin I.A.

(C) 2021, Grishin S.E., Ulyanov V.Yu., Fedonnikov A.S., Norkin I.A.

(C) 2021, Saratov Medical Journal

\begin{abstract}
:
Background. The formation and development of industrial model for social processes and systems in the early twentieth century brought to life a novel form of organizing scientific activity via establishing research institutions.

Objective. This study aimed to investigate the gaps in the history of traumatology institutions in the early years of the Soviet State.

Materials and methods. We carried out a comprehensive analysis to retrieve the data from both State and institutional archives, as well as from the literature sources. The narrative analysis was chosen as the method of data interpretation. Most archive documents are made available to the scientific community for the first time. Our study covered the period of time from 1917 to 1930. Over 500 sources were analyzed.

Results. We established that the first five traumatology institutions were founded in the following sequence: Saratov Traumatology Institute in 1919, Rostov Traumatology Institute in 1920; Astrakhan, Moscow Oblast, and Voronezh Traumatology Institutes in 1921. The concept of research institution was mainly designed to achieve the systematic augmentation of scientific knowledge and form a new employee type called a professional scientist.

Conclusion. Discovering the history of establishing first traumatology institutions that provided healthcare services and conducted independent scientific studies led us to defining a new, previously unexplored institutionalization stage of Russian traumatology and orthopedics. In the early years of the Soviet State, research institutions facilitated the development and implementation of efficient medical technologies into healthcare practice.
\end{abstract}

Keywords: history of traumatology and orthopedics, research institute, traumatology institution.

Cite as Grishin SE, Ulyanov VYu, Fedonnikov AS, Norkin IA. Saratov Medical Journal 2021; 2 (1): eo102.

Correspondence to Sergei E. Grishin, Tel.: +7(927)1222498, E-mail: bib@sarniito.com

\section{Introduction}

The formation and worldwide development of industrial model for social processes and systems in early twentieth century launched a novel form of organizing scientific activity via establishing research institutions. As the most important social subsystem, public healthcare system accepted this challenge. This was reflected in the search for new organizational forms of scientific and clinical work, particularly in the fields of traumatology and orthopedics, which were among the most demanded branches of medical science and practice.

The bibliography guide, compiled by S.A. Jokhelson and S.Ya. Freidlin [1], contains 2110 bibliographic entries of the publications by Russian trauma surgeons in 1924-1933. That is why, we consider it a valuable source of information on the traumatology history in the 1920 , as well as two extensive, even though underestimated, published studies by K.K. Silvay that essentially constitute medical historiography published during the Soviet period $[2,3]$. The publications are arranged by pathology descriptions, or by listing Russian scientists, whose contributions to traumatology are still poorly known.
The institutional aspect of trauma and orthopedics development remains barely studied at all, except for a few publications [4]; therefore, it is for the reason that the establishment and functioning of traumatology institutions in the early years of the Soviet State remain a gap in the history of medical science. Their operation, as well as their existence per se, remains poorly studied, making bridging this research gap the necessity.

\section{Materials and Methods}

We searched through the following information sources: the central catalog at the Archive Fund of the Russian Federation, State Archive of the Russian Federation collections, the State Archive of Saratov Oblast, the State Archive of Contemporary History of Saratov Oblast, the archive of the Research Institute of Traumatology, Orthopedics and Neurosurgery, the archive of V.I. Razumovsky Saratov State Medical University (SSMU), electronic and paper media catalogs at the Russian State Library, the Federal Electronic Medical Library at the Ministry of Healthcare of Russia, the image catalog of the Central Scientific Medical Library at the I.M. Sechenov First 
Moscow State Medical University (Sechenov University), the scientific library catalog at N.G. Chernyshevsky Saratov State University, the scientific library catalog at SSMU, the PubMed ( $>500$ sources) MEDLINE database, and resources of scientific electronic library eLIBRARY.ru

Whereas our search in libraries and information resources was carried out by keywords and chronological periods, examination of the archives had a four-layer design: by catalog cards, keywords, chronological periods and archival collections. Both institutional and personal collections were analyzed. As for the method of collecting information, we conducted the comprehensive analysis of state and departmental archives and published sources. The leading method for describing the obtained data was narrative analysis. Most archival materials are introduced into scholarly discourse for the first time. Our study covered the period of time from 1917 through 1930.

\section{Results}

The Volga Region was the first area in Russia to establish institutions aimed at solving both scientific and medical issues in traumatology and orthopedics. The establishment of the Orthopedic Institute at the premises of the Surgery and Orthopedic Hospital in Kazan on November 1, 1918 was initiated by Professor M.O. Friedland. It had a hospital for 40 beds, a prosthetic workshop with 30 employees and an orthodontic department [5]. However, other sources claim that it was the Surgery and Orthopedic Hospital that Professor M.O. Friedland founded in November 1918 [6]. Either way, it was 1918, when the history of establishing specialized scientific medical institutions has started. The conventional approach to the history of Russian traumatology and orthopedics states that the institute established by N.N. Priorov in 1921 in Moscow was the next one to follow [7]. However, the thorough investigation of the 1916-1930 archive files allowed us identifying that the first Traumatology Institute nationwide was established in Saratov by Professor S.I. Spasokukotsky.

Pursuing his strong interest in traumatology, in 1918, S.I. Spasokukotsky submitted a proposal to Saratov Healthcare Department to establish a trauma institute for treating primarily wounded Red Army soldiers [8]. On June 29, 1919, at the meeting of Saratov Province Healthcare Department, the costs for the trauma institute were approved [9] launching the official start of its operation.

The fact of Saratov Trauma Institute establishment and actual existence was confirmed by numerous sources of various origin encountered by the authors of this study. Here we quote a document found in the archives, 'In 1919 Saratov was enriched with a new establishment - the Traumatology Institute setting itself the task of rehabilitating war invalids and disabled workers' [10]. The Institute was Professor S.I. Spasokukotsky's brainchild. He was not just the Chair of the University Hospital Surgery Division but also the Chief Physician of the institute [11]. As of 1920, its stuff comprised 196 employees [12], including 13 doctors, 26 feldshers, and 12 nurses [13]. By October 5, 1920, it had 250 hospital beds [14]. The institute also included a Primary Party Organization of the Russian Communist Party of Bolsheviks No. 53 consisting of 23 party members in 1919 [15], and 10 members in 1921 [16].

S.I. Spasokukotsky established three divisions within the institute: Division of Surgery, Division of Orthopedics and Division of Nervous Diseases. Because of ongoing famine, many of the researchers and physicians, such as future famous Russian trauma orthopedists Aleksandr G. Eletsky, who was the head of the Surgery Division, and Spasokukotsky's disciples N.I. Krause and N.V. Almazova, who worked at the same division, as well as others had to work several jobs [17]. Sergey I. Spasokukotsky had three jobs: at the Traumatology Institute, at the University Clinic, and at the department of the university.

Of 23 medical institutions providing medical care in Saratov, the Traumatology Institute was the only establishment to carry out research and teaching [18]. The Institute trained skilled professionals in the field of surgery and traumatology. We could not restore full lists of residents and interns; however, we discovered that in 1920-1922 future Professor and Vice Chancellor for Academic Affairs of Tomsk Medical Institute, Isaac S. Vengerosky, was among the Institute's residents [19]. From 1920, Aleksandr N. Spiridonov, future Chair of the Hospital Surgery Department at Saratov Medical Institute, was an intern at Saratov Traumatology Institute [20]. Ilya A. Golyanitsky has also graduated from Saratov Traumatology Institute residency [21]. While being a resident, he established a heliotherapy resort at the institute for surgery patients [22]. In February 1921, the four-month course for lower-level medical personnel was launched [23]. The medical research was also carried out very intensively. For instance, the clinical part of A.G. Eletsky's DSc dissertation was completed entirely at Saratov Traumatology Institute [24].

Saratov Traumatology Institute set an example of effective transition from the projects by individual researchers and enthusiasts to the teamwork. The concept of the research institution was mainly designed to achieve the systematic augmentation of scientific knowledge and form a new employee type called a professional scientist. Being a part of a social reality, the institute served as the base for initial forms of professional scientific collaboration involving numerous actors, which facilitated the development and implementation of the efficient medical technology into the healthcare practice. The Saratov model was soon used for establishing and developing traumatology institutions in other regions nationwide [25].

As a result of the comprehensive investigation of the archive documents, we can confirm the fact of establishing five trauma institutes in Russia: Saratov Traumatology Institute in 1919; Rostov Traumatology Institute in 1920; Astrakhan, Moscow Oblast, and Voronezh Traumatology Institutes in 1921 [26-31]. Their establishment can be considered within the framework of both medical and social consequences of two wars - World War I and the Civil War.

In 1920, in Rostov-on-Don, a trauma institute was founded on the initiative of professor Nikolay V. Pariysky. The clinical facility of the institution was represented by the orthopedic (80 beds) and neurological (6o beds) departments. Rostov Traumatology Institute employed three professors: N.V. Pariysky, N.A. Bogoraz, and K.S. Agadzhanyants [32]. In two years, the Institute was transferred to the Military Medical Department.

In 1921, the former resident doctor of Saratov Traumatology Institute I.A. Golyanitsky founded Astrakhan Traumatology Institute. Golyanitsky was already a famous scientist prior to his residency, and he worked as a physician at the surgical clinic of the medical institute headed by professor S.I. Spasokukotsky. 
On April 4, 1921, Astrakhan Province Public Healthcare Department agreed to Prof. I.A. Golyanitsky's initiative on the establishment a trauma institute using Saratov Traumatology Institute as an example. It started operating on September 10, 1921, on the premises of the former religious college. The following data illustrate the extent of the clinical operation of the institute. Every month they were seeing as many as 300 patients there, the total of 3,851 visits in 11 months. Over the period of the institute's existence, 3,124 surgeries were performed (Figure). There was a prosthetic workshop established at the institute that manufactured prostheses, orthopedic devices, braces, etc.

Astrakhan Traumatology Institute was initially opened with 120 hospital beds but later their number was cut in half. The institute's operation was terminated on August 1, 1922, due to lack of available funds at the Province Healthcare Department. The orthopedic research and practice moved to the surgical clinic at the medical institute, where Prof. I.A. Golyanitsky managed to allocate 12 beds for orthopedic patients. Over the short time of the institute existence, a great effort was expended on the establishment of orthopedic science in Astrakhan.

It was solely Moscow Traumatology Institute (N.N. Priorov National Medical Research Center for Traumatology and Orthopedics at present) of all described above institutions that survived until the twenty-first century.

\section{Discussion}

The first half of the twentieth century in most developed countries worldwide was the formation time of the new form of scientific organization - research institutions [34]. We uncovered the facts on the establishment of traumatology institutes. The latter could be considered examples of the dynamic development of new organizational forms of systematic scientific teamwork during the period from 1917 to 1929.

Before the research institutions were founded, the medical science in the field of surgery was organized in the following way: the leading organizational form involved academic departments and clinics dominated by teaching and therapy, respectively. The organization of science was informally presented in surgical scientific societies as a form of expression and social activity, along with congresses of surgeons as a necessary practical form of academic communication.

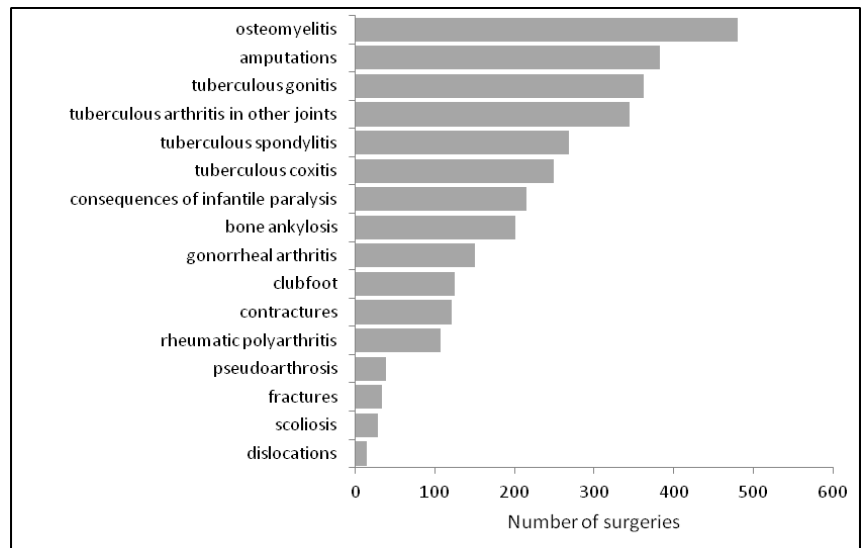

Figure. Causes and frequencies of occurrence of surgeries performed at Astrakhan Traumatology Institute in 19211922. Calculated by the authors, according to the source [27, p. 32-33]

(C) 2021, Saratov State Medical University, Saratov, Russia

(C) 2021, LLC Innovative Medical Technologies, Saratov, Russia

(C) 2021, LLC Science and Innovations, Saratov, Russia
In our opinion, there were four complex factors facilitating the development of the new form of institutional activity in the field of medical research work - a traumatology institute:

1) Sociomedical factor: the large number of disabled people after World War I and the Civil War. Although there were numerous prosthetic workshops nationwide, they did not solve the problem of quality treatment for these patients;

2) Sociopolitical factor: the substitution of former approaches and traditions as a result of new social system formation after the October Revolution of 1917;

3) Socioeconomic factor: reduction of the conditions for conducting research to the minimum amidst political instability, which led to the search for new effective practices ensuring the mere survival of scientists;

4) Sociocultural factor: in the first years after the October Revolution of 1917, the Bolshevik ideology resulted in cultural degradation. It is worth remembering that chancellors and deans were elected by students and social groups, who/which did not directly participate in scientific research. As a consequence, the establishment of a research institution was, on some occasions, a form of social opposition to cultural degradation.

The value of traumatology institutes, founded by S.I. Spasokukotsky and his followers, was in the formation of a positive attitude towards a new form of organizing the medical science in the political elite of the country. A quarter of a century later, research institutes would become a habitual constituent of the Russian scientific landscape.

The establishment of first Russian trauma institutes was a manifestation of the formation of traumatology and orthopedics based on a model, in which the major role in organizational processes was assigned to direct initiators (in this case, scientists) of a new organizational practice formation $[4$, p. 372].

\section{Limitations}

It may be suggested that there were other traumatology institutions, up to now unknown, in Russian regions, and their operation may be traced in the regional archives of the Russian Federation. Although the central catalog at the Archive Fund of the Russian Federation, encompassing the funds of both central authorities and all subjects of the federation, provides information on 697 cases of traumatology institutes, the vast majority of these cases ( $>90$ $\%)$ actually relate to $1948-2000$. There are just seven records for 1917-1930s, of which two cases from the State Archive of the Russian Federation had to be excluded after thorough investigation. First, despite the archival description, information about the existence of the Tomsk Traumatology Institute was not confirmed. The report on Leningrad Orthopedic Institute was filed to the case 'Annual Reports on the State and Operation of: 1. Tomsk Physiotherapeutic Institute; 2. Tomsk Roentgenological Institute; 3. Tomsk Radio-Roentgenological Institute; 4. Tomsk Traumatological Institute' [31]. Second, despite the annotation, in another case, there is no petition to allocate funds for the organization of a trauma institute in Tiflis from the chief of the medical unit of the Caucasian Front armies [32].

The authors defined a number of issues hindering this kind of investigation:

- The funds may relocate among the regional archives. The relocation may take years, and during this period the 
funds are unavailable for researchers. They are renumbered and renamed after the relocation making the investigation even more difficult;

- The library collections are in the process of digitalization, and they limit access to the conventional systematic catalogs sending users to digital records. However, the comparison of digital and conventional catalogs in many libraries confirms that paper-based catalogs are much more complete for the time period under study;

- There are significant differences in the thesauruses of record managers, archivists, and medical historians. As a result, the documents on the history of traumatology and orthopedics may be filed irrelevant materials. If we fail to perform a thorough review of all pages in the files, guided by our logic and research experience rather than formal directions of archive experts, we may spend years searching for the information and never discover it.

A recurrent immersion in the information that accompanied the years of revolutionary transformations, where each carefully studied 3-6 months may give new insights, would lead to the discovery of unknown facts in the history of Russian traumatology and orthopedics. In the future, if new data are revealed, it would be possible to carry out a comparative analysis of the activities of Russian trauma institutes in the 1920 s.

\section{Conclusion}

Discovering the history of establishing first traumatology institutions that provided healthcare services and conducted independent scientific studies led us to defining a new, previously unexplored stage of Russian traumatology and orthopedics development associated with the formation of a system of specialized institutes. The latter were the basis for the systematic accumulation of new knowledge and the development of effective medical technologies for the healthcare system.

\section{Acknowledgements}

The study was conducted in accordance with the Initiative Plan of Scientific Research Framework of Research Institute of Traumatology, Orthopedics and Neurosurgery, Saratov State Medical University of the RF Ministry of Healthcare "Comprehensive analysis of establishment and development of traumatology, orthopedics and neurosurgery in Russia". Registration number: AAAA-A20-120022190006-9.

\section{Conflict of interest}

The authors declare no conflict of interest.

\section{References}

1. Iokhelson SA, Freidlin SYa. The 10 Years of Bibliography on Russian Traumatology (1924-1934). Ed. Prof. S.S. Girgolav. Leningrad: OGIZ, 1936. (In Russian).

2. Silvay KK. The history of Soviet orthopedics and traumatology: Bibliographical review (1917-1967); Part 1. Orthopedics, Traumatology and Prosthetics 1971; (8): 81-86. (In Russian).

3. Silvay KK. The history of Soviet orthopedics and traumatology: Bibliographical review (1917-1967); Part 2. Orthopedics, Traumatology and Prosthetics 1971; (10): 74-82. (In Russian).
4. Grishin SE, Demidova EI, Puchinyan DM, et al. The institutionalization of traumatology and orthopedics in Russia. Problems of Social Hygiene, Public Health and History of Medicine 2017; 25 (6): $371-374$ (in Russian). https://doi.org/10.18821/0869-866X-2017-25-6-371-373.

5. Bogdanovich UYa, Khabibiyanov RYa, Karimov MG. History of development and establishment of Tatarstan Research Center of Reconstructive Traumatology and Orthopedics. Kazan Medical Journal 2009; 90(1): 135-138. (In Russian).

6. Akhtyamov IF, Pankov IO. The centenary of Kazan school of traumatology and orthopedics. Traumatology and Orthopedics in Russia 2018; 24(3): 157-162. (In Russian).

7. Tkachenko SS. The progress of traumatology and orthopedics in 70 years of Soviet rule. I.I. Grekov Bulletin of Surgery 1987; (9): 3-10. (In Russian).

8. Korotkikh RV. Spasokukotsky and His Medical School. Moscow: Meditsina, 1983. (In Russian).

9. The State Archive of Saratov Oblast. Fonds R-521, Register 1, Case 329, Sheet 35. (In Russian).

10. The State Archive of Saratov Oblast. Fonds R-229, Register 1, Case 295, Sheet 47. (In Russian).

11. The State Archive of Saratov Oblast. Fonds R-229, Register 1, Case 315, Sheet 3 reverse. (In Russian).

12. The State Archive of Saratov Oblast. Fonds R-229, Register 1, Case 309, Sheet 11 reverse. (In Russian).

13. The State Archive of Saratov Oblast. Fonds R-229, Register 1, Case 309, Sheet 7. (In Russian).

14. The State Archive of Saratov Oblast. Fonds R-229, Register 1, Case 309, Sheet 13 reverse. (In Russian).

15. The State Archive of Contemporary History of Saratov Oblast. Fonds R-3852, Register 1, Case. 1, Sheet 9. (In Russian).

16. The State Archive of Contemporary History of Saratov Oblast. Fonds R-3852, Register 1, Case. 2, Sheet 7. (In Russian).

17. Spiridonov AN. The history of Saratov Medical Institute Department of Hospital Surgery: On half-century anniversary. Topical Issues of Surgery (Saratov) 1965; 47(64). (In Russian).

18. The Sirectory of Saratov Province Medical Department. Saratov, 1921. (In Russian).

19. Maslikov VM, Shalygin VA, Melnik DN. Vengerovsky, Isaac Solomonovich: On the 110th anniversary. Bulletin of Siberian Medicine 2007; (4): 122-123. (In Russian).

20. The archive of the Research Institute of Traumatology, Orthopedics and Neurosurgery of of Saratov State Medical University. Register 1 front, Case 495, Sheet 2 back.

21. The State Archive of Saratov Oblast. Fonds F-229, Register 1, Case 315, Sheet 3 back. (In Russian).

22. Zurnadzhan SA, Levina TA. Ilya Alekseevich Golyanitsky (18881939). Proceedings on the History of Medicine. Almanac. Issue 3 Moscow: HELENPRO Ltd., 2018. 157-163. (In Russian).

23. 23. The State Archive of Saratov Oblast. Fonds F-229, Register 1, Case 295, Sheet 106. (In Russian).

24. Eletsky AG. Resection of the dorsal roots of the spinal cord as a treatment for spastic paralysis (Foerster's operation). Saratov, 1924. 255. (In Russian).

25. Spasokukotskaya MG. Life and Career of S.I. Spasokukotsky. 1870-1943. Moscow: Medgiz, 1960. 148. (In Russian).

26. The State Archive of the Russian Federation. Fonds A-482, Register 3, Case 255. (In Russian).

27. Orthopedics in Astrakhan. Medical survey of the Lower Volga Region. The Publication of Astrakhan District Healthcare Department. July-August 1928; 7-8: 39-42. (In Russian).

28. The State Archive of the Russian Federation. Fonds A-482, Register 28, Case 214. (In Russian).

29. The State Archive of Voronezh Oblast. Fonds R-1145, Register 1, Case 33. (In Russian).

30. The State Archive of Voronezh Oblast. Fonds R-35, Register 1, Case 704. (In Russian). 
31. The State Archive of Voronezh Oblast. Fonds R-35, Register 1, Case. 580. (In Russian).

32. Sikilinda VD, Filonov IL, Maslov AI, et al. The origins of the Don orthopedics: On centenary anniversary of higher education medical school in Rostov-on-Don. Journal of Fundamental Medicine and Biology 2014; 3: 61-63. (In Russian).

33. Golyanitsky IA. Treatment of echinococcus disease. In: Proceedings of the 22nd Congress of Surgeons 1912. (In Russian).

34. Science in America, a Documentary History, 1900-1939. Eds. Reingold N, Ids IH. The Chicago History of Science and Medicine. University of Chicago Press, 1981: 221.

35. The State Archive of the Russian Federation. Fonds A-482, Register 10, Case 1153. (In Russian).

36. The State Archive of the Russian Federation. Fonds 6787, Register 1, Case 56. (In Russian).

Authors:

Sergei E. Grishin - DSc, Professor, Head of the Division of Bibliography and Documentation Support, Research Institute of Traumatology, Orthopedics and Neurosurgery, Saratov State Medical University, Saratov, Russia. ORCID oooo-0002-0990-4175;

Vladimir Yu. Ulyanov - DSc, Deputy Director for Science and Innovations, Research Institute of Traumatology, Orthopedics and Neurosurgery, Saratov State Medical University, Saratov, Russia. ORCID 0000-0002-9466-8348;

Aleksander S. Fedonnikov - PhD, Assistant Professor, Vice Chancellor for Research, Head of the Division of Technological Innovation in Healthcare and Rehabilitation, Research Institute of Traumatology, Orthopedics and Neurosurgery, Saratov State Medical University, Saratov, Russia. ORCID oooo-0003-0344-4419;

Igor A. Norkin - DSc, Professor, Deputy Director for Development, Research Institute of Traumatology, Orthopedics and Neurosurgery, Chair of the Department of Traumatology and Orthopedics, Saratov State Medical University, Saratov, Russia. ORCID 0ooo-0002-67703398 